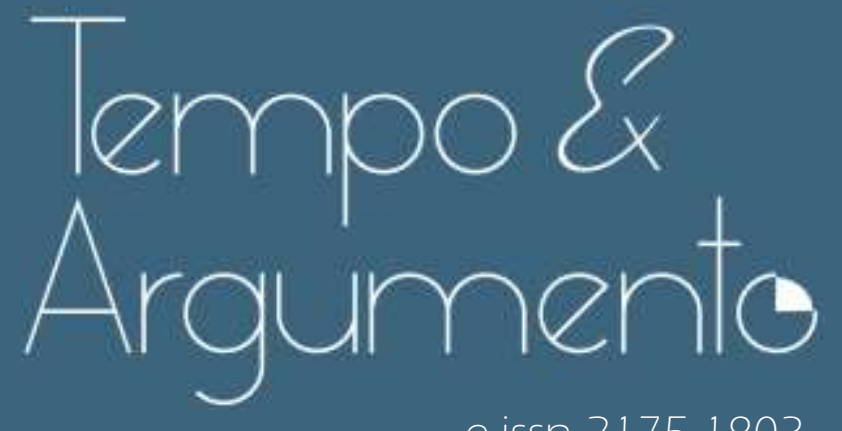

e-issn 2175-1803

\title{
A teoria da degeneração e suas implicações no Hospital de Doenças Nervosas e Mentais. Recife, PE / 1920
}

- Carlos Alberto Cunha Miranda

Doutorado em História pela Universidade Federal de Pernambuco (UFPE).

Professor associado na Universidade Federal de Pernambuco (UFPE).

Recife, PE - BRASIL

cunhamirandaufpe@gmail.com

(D) orcid.org/0000-0002-7231-352X

Para citar este artigo:

MIRANDA, Carlos Alberto Cunha. A teoria da degeneração e suas implicações no Hospital de Doenças Nervosas e Mentais. Recife, PE / 1920. Tempo e Argumento,

Florianópolis, v. 13, n. 33, e0115, maio/ago. 2021.

do http://dx.doi.org/10.5965/2175180313332021e0115

Recebido: 17/01/2021

Aprovado: 21/04/2021 


\title{
A teoria da degeneração e suas implicações no Hospital de Doenças Nervosas e Mentais. Recife, PE /1920
}

\begin{abstract}
Resumo
Neste artigo, inicialmente apresentaremos o conceito de degeneração desenvolvido por Benedict-Augustin Morel, Valentin Magnan e Emil Kraepelin, bem como suas repercussões na psiquiatria brasileira nos primeiros anos do século XX. Com base nesses pressupostos, discorreremos sobre a trajetória de vida de pessoas consideradas portadoras de transtornos mentais e do saber psiquiátrico no Hospital de Doenças Nervosas e Mentais do Recife, através da análise de alguns prontuários dos anos de $1920 \mathrm{com}$ pacientes diagnosticados como portadores de Episódio Delirante de Degeneração. O suporte desta pesquisa está no trabalho desenvolvido no acervo do Hospital Ulysses Pernambucano, em que foi realizado o resgate da documentação, a catalogação e a edição de um inventário de todos os livros entre os anos de 1926 a 1970, no total de 1013 volumes, cada um com cinquenta prontuários. A análise dessas importantes fontes, juntamente com o aporte teórico, permitiu a elaboração desse artigo.
\end{abstract}

Palavras-chave: Hospital; psiquiatria; degenerados; eugenia.

The theory of degeneration and its implications in the Hospital of Nerve and Mental Diseases. Recife, PE /1920

\begin{abstract}
In this article, we will initially present the concept of degeneration developed by Benedict-Augustin Morel, Valentin Magnan and Emil Kraepelin, as well as its repercussions on Brazilian psychiatry in the early years of the 20th century. Based on these assumptions, we will discuss the life trajectory of people considered to have mental disorders and psychiatric knowledge at the Hospital for Nervous and Mental Diseases of Recife, through the analysis of some medical records from the 1920s with patients diagnosed with the Delusional Episode Degeneration. The support of this research is in the work developed in the collection of the Hospital Ulysses Pernambucano, in which the recovery of documentation, cataloging and the edition of an inventory of all books between the years 1926 to 1970 was carried out, in a total of 1013 volumes, each with fifty records. The analysis of these important sources, together with the theoretical contribution, allowed the elaboration of this article
\end{abstract}

Keywords: Hospital; psychiatry; degenerate; eugenics. 


\section{Introdução}

No século XIX, surgem novas concepções de prisões, fábricas, hospitais e instituições asilares com inovações em suas formas arquitetônicas. Foi a época das grandes reformas urbanas e do crescimento das cidades, das ideias higienistas, eugenistas, evolucionistas e da bacteriologia. Enfim, um período em que teorias, práticas científicas e doutrinas foram aplicadas com maior intensidade sobre o homem em nome da ordem social vigente.

Para a elaboração deste artigo, partimos da premissa de que a constituição do saber psquiátrico não é atributo apenas dos seus postulados, mas decorrente de uma conjuntura sociocultural e política em que a pessoa considerada portadora de transtorno mental e seus familiares estão inseridos. Dessa forma, procuramos contextualizar as teorias que alicerçaram o conceito de degeneração e resgatar dados importantes sobre a história de algumas pessoas, inclusive crianças e adolescentes em situação de sofrimento psíquico, junto às suas famílias ou não, quando passaram pelo Pavilhão de Observação e que, posteriormente, foram internados no Hospital de Doenças Nervosas e Mentais (H.D.N.M) com o diagnóstico de degenerados. Esse espaço não era apenas destinado à prática médica, mas esteve inserido em meio às mudanças significativas que ocorreram no século XIX.

As ideias de Augusto Comte, tanto como doutrina quanto método, passam a dominar o pensamento da sociedade a partir de meados do século XIX. Enquanto doutrina, apresentava-se, na época, revelando a própria ciência, ou seja, com caráter universal da realidade e com significado geral da dinâmica do universo. Metodicamente estava embasada na certeza rigorosa dos fatos da experiência como fundamento da construção teórica. Entre os intelectuais mais claramente autoritários, a exemplo de médicos e bacharéis, "essa doutrina veio ao Brasil mesclada com outros modelos teóricos em voga na Europa, tais como o Darwinismo Social e o Evolucionismo de Spencer, que constituíram, tanto quanto o positivismo, a base do seu cientificismo" (HERCHMANN, 1994, p. 57). Por sua vez, para a psiquiatria, baseada no conceito de processo mórbido em que a loucura é uma evolução doentia da mente desprovida de razão, as pessoas eram consideradas anormais patologicamente e incapazes de raciocinar. Os escritos 
de Robert Castel e Michel Foucault propiciaram um terreno fértil para o estudo dos hospitais psiquiátricos, engendrando discussões a respeito do papel político e social dos saberes nas instituições psiquiátricas (OUYAMA, 2010, p. 147). Enfim, a doutrina positivista permitiu, especialmente aos médicos, construir um modelo explicativo que vigorou durante décadas do século XX.

A função social da assistência manicomial era basicamente garantir a segregação das pessoas consideradas perturbadoras da ordem pública, julgadas irracionais e perigosas, cuja administração foi delegada ao conhecimento psiquiátrico, em instituições asilares. Goffman conduz um estudo sobre o hospital psiquiátrico em que descreve processos sociais que se desenrolam em suas instalações internas, demonstrando os esforços sistemáticos dentro da instituição para desacreditar e fazer fracassar as tentativas desenvolvidas pelos portadores de transtornos mentais para manter intacta a sua identidade (GOFFMAN, 1987). Assim, fica evidente que a organização dos hospitais psiquiátricos, empregando a terapêutica de Pinel ou Kraeplin, eram incapazes, na época, de responder às mínimas exigências de uma vivência adequada e "humanizada" nessas instituições.

\section{O saber psiquiátrico e os princípios de degeneração}

A classificação de "alienação mental" foi estabelecida por Philippe Pinel (1745-1826) em quatro grandes grupos: mania, melancolia, demência e idiotia, complementados por Jean Dominique Esquirol (1772-1840). Ao elaborar a sua nosografia da alienação, no Tratado Médico-Filosófico da Alienação Mental, datado de 1809, valorizou sobremaneira as "paixões ardentes" sem desconsiderar as lesões do sistema nervoso, a hereditariedade, as influências da educação e os desregramentos dos costumes como causas da loucura. Para Pinel, as "paixões" carregavam vários significados: vício, sofrimento, desavença conjugal, ira, atitude violenta, amor ardente, medo etc. (PHILIPPE, 2007).

Ambos admitiam que a alienação era, sobretudo, uma desordem do comportamento e se ela insurgia contra a ordem social, a terapêutica só poderia ser realizada pela imposição de determinadas normas através de um processo de reeducação do alienado - "tratamento moral" - efetivado num hospício, longe 
da interferência da sociedade e principalmente da família e dos amigos. Afastados de toda comunicação com os seus parentes e amigos, passavam a se submeter às novas diretrizes. Baseados nessa doutrina, os hospícios na Europa e no Brasil foram construídos e a terapêutica do isolamento instituída.

No século XIX, o campo da anormalidade se constitui quando esse conceito surge como categoria médica: "os anormais, os deficientes mentais e os 'franco alienado' tornam-se objeto do mesmo discuro científico e são todos incluídos por Juliano Moreira na categoria e estados psicopáticos" (PORTOCARRERO, 2002, p. 62) Assim, a psiquiatria não apenas se limitou às loucuras ativas e demências, mas articulou suas práticas especialmente sobre as "anomalias", aquelas que se apresentavam de forma silenciosa e que se delineavam em pequenos detalhes. A constituição do conceito de degeneração legitimou os psiquiatras a intervirem no campo social de forma mais efetiva. Assim, as causas da loucura se ampliaram e se tornaram o contraponto da predominância atribuída aos fatores morais. Referindo-se a esse novo campo da psiquiatria, Foucault afirma:

Vocês estão vendo, como nessas condições, a psiquiatria pode efetivamente, a partir dessa noção de degeneração, a partir dessas análises da hereditariedade, conectar-se, ou antes, dar lugar a um racismo, um racismo que foi nessa época muito diferente do que poderíamos chamar de racismo tradicional, histórico, "o racismo étnico". O racismo que nasce com a psiquiatria dessa época, é o racismo contra o anormal, é o racismo contra o indivíduo, que, sendo portador seja de um estado, seja de um estigma, seja de um defeito qualquer, pode transmitir a seus herdeiros. (FOUCAULT, 2001, p. 403)

Vistos esses pressupostos, no final do século XIX e início do XX, três teorias passaram a exercer uma grande influência no meio da psiquiatria brasileira: a concepção de degenerescência de Benedict-Augustin Morel (1808-1873), em seu Traité des Dégénérescences, publicado em 1857; as noção de "loucuras hereditárias" e "loucuras morais", de Valetin Magnan (1835-1916); e o organicismo e a temática de "herança mórbida", de Emil Kraepelin (1856-1926) (CAPONI, 2012a).

Para Morel, as degenerações eram desvios doentios pronunciados das qualidades originais do homem, sob a ação de fatores e circunstâncias involuntárias, transmitidos hereditariamente e que lesionavam as células do sistema nervoso - a intoxicação. Nesse sentido, a essência da doutrina consistia 
no postulado da transmissão à descendência das "taras", vícios e traços mórbidos adquiridos pelos antecessores. Segundo o médico francês, a medida que o germe patológico era transmitido através das gerações, seus efeitos se agravavam e os descendentes desciam os degraus da decadência física e moral até "a esterilidade... a imbecilidade, a idiotia, e, finalmente a degenerescência cretina". Ao fim do percurso, a linhagem afetada se extinguiria por si só, por uma espécie de eliminação natural. A influência concreta da família sobre a criança desempenharia um papel central na instalação da degeneração nos indivíduos. Foucault escreveu que "será chamada de 'degenerada' a criança sobre a qual pesam, a título de estigmas ou de marcas, os restos da loucura dos pais e dos antecedentes. A degenerescência é, portanto, de certo modo, o efeito da anomalia produzido na criança pelos pais" (FOUCAULT, 2006, p. 282).

Entre os indicativos da degeneração nos indivíduos, destacam-se os estigmas físicos -

assimetria ou deformação da cabeça, da face e dos membros - e os de ordem moral ou intelectual: o retardo mental, a tara, o cretinismo e a imbecilidade. Contudo, nem todos os estigmas da degeneração eram evidentes, muitos deles ficavam ocultos e passavam despercebidos como anomalias na estrutura dos órgãos.

Diagnosticada em função das influências patológicas e sociais, a degeneração seria, para os psiquiatras, a grande responsável por uma elevada taxa de criminalidade, delinquência e loucura. Dessa forma, o conceito de degenerescência, transmitida de geração a geração, ampliou significativamente a noção de "insanidade mental", criando novos rótulos para as condutas coletivas e individuais - a anormalidade moral.

No final do século XIX, Valentin Magnan, em consonância com Morel, formulou a constituição da categoria dos hereditários degenerados que é a junção entre o "retardo mental" e o "distúrbio de caráter", dividindo-os em quatro classes: idiotas, imbecis, débeis mentais e degenerados superiores, sendo as duas últimas amoldadas às loucuras degenerativas. Em prosseguimento às suas análises, Magnan classificou a loucura dos hereditários degenerados em quatro grupos: 1. idiotia, imbecilidade e debilidade mental; 2. anomalias cerebrais (estado 
mental dos desequilibrados); 3. síndromes episódicas; 4. delírios propriamente ditos: nascido no terreno do desequilíbrio mental e dele extraíam características particulares que permitiam reconhecê-lo clinicamente (BERCHERIE, 1989, p. 154).

A busca incessante e minuciosa que indicasse sinais expressivos de traços anatômicos de degenerescência nos cérebros de cadáveres perdurou durante muitas décadas nas aulas de anatomia das faculdades de medicina e nos laboratórios médico-legais. Como não era possível visualizar as anomalias no cérebro das pessoas vivas ou através de necropsias daqueles que recebiam diagnóstico de degenerados, optou-se por observar os caracteres externos a fim de melhor definir a anormalidade (LOUGAN, 2006, p. 64). Ressalta Castel que a teoria da degenerescência, fundamentada sobretudo por Magnan, exerceu uma influência decisiva no futuro da psiquiatria, operando uma verdadeira reviravolta em relação à concepção de alienação mental (CASTEL,1978, p. 259). Um exemplo de grande aceitação por parte dos alienistas brasileiros da teoria de Morel e Magnan são os diagnósticos fornecidos aos pacientes do Hospício Nacional de Alienados no começo do século XX, em que $90 \%$ dos casos analisados foram classificados como degenerados atípicos (RESENDE, 1990, p. 44).

Com as descobertas no campo da neurologia, consolidava-se a ideia da possibilidade das desordens do comportamento humano virem a ser explicadas pelo funcionamento anormal dos cérebros e de possíveis lesões. As concepções da psiquiatria alemã, de Emil Kraepelin, favoreceram os estudos anatomopatológico e farmacológico. A concepção organicista passou a direcionar as práticas terapêuticas nos hospícios. Assim, nos anos 1920, os tratamentos nos Hospícios foram direcionados para interferir diretamente sobre a lesão no cérebro, mais especificamente sobre o sistema nervoso. Esse procedimento tinha como objetivo alterar o estado do encéfalo e, através dele, os comportamentos desviantes. Aspectos das teorias sobre a degeneração reaparecem nos escritos de Kraepelin.

Sandra Caponi esclarece que, no ano de 1908, Emil Kraepelin publicou algumas teses formuladas pelos teóricos da degeneração. O primeiro texto, intitulado "Sobre a questão da degeneração", permite entender de que modo Kraepelin integrou o seu discurso à problemática da hereditariedade mórbida. No 
A teoria da degeneração e suas implicações no Hospital de Doenças Nervosas e Mentais. Recife, PE /1920

Carlos Alberto Cunha Miranda

entanto, a preocupação pelas doenças psiquiátricas hereditárias ou degenerativas não pode ser circunscrita a esse escrito, pois a questão da herança mórbida e da degeneração se manteve constante nas oito edições de seu livro fundamental: Psiquiatria clínica, também conhecido como Manual de psiquiatria. Ainda segundo a autora, trata-se de um tema recorrente, inclusive em textos como as Leituras de psiquiatria clínica (1913) e As formas de manifestação da insanidade (1920) (CAPONI, 2012b, p. 29).

O agrupamento nosográfico do psiquiatra alemão, inserido em sua obra Die Klinischen Formen des Irreseins (Introdução à Clínica Psiquiátrica), foi divulgado nos Arquivos Brasileiros de Neurologia e Psiquiatria e contemplava: “Estados Mórbidos Congênitos: irritáveis, instáveis, instintivos, disputadores, mentirosos e fraudadores, anti-sociais, exaltados e fanáticos; e Oligofrenias: idiotia, imbecilidade, debilidade, mongolóide e infantilismo" (LOPES, 1960).

Nos primeiros anos do século XX, o ecletismo da psiquiatria brasileira, ao adotar alguns preceitos de Pinel juntamente com a psiquiatria ampliada, colaborou para a internação nos hospícios de novos personagens: agora, não são só os loucos mansos, os furiosos e os delirantes os habitavam, mas também indivíduos que apresentavam uma loucura invisível, os degenerados e os loucos morais, todos portadores de comportamentos estranhos e rebeldes. Essa concepção de loucura criou uma nova classe de pessoas avaliadas mentalmente doentes e perigosas. Ainda nesse século, a psiquiatria ampliou consideravelmente o seu campo de atuação, possibilitando não só a classificação do degenerado alienado, mas também do degenerado epiléptico, alcoólatra, sifilítico e de todos aqueles que apresentavam uma conduta incompatível com a ordem social vigente. Segundo Vera Porto Carrero, a psiquiatria expandiu seu campo de intervenção, estabelecendo uma diferença fundamental entre os casos de doença mental e de degeneração moral. A noção de degenerescência vai justificar a intervenção do conhecimento psiquiátrico em todo campo das práticas ponderadas anormais (PORTOCARRERO, 2002, p. 60). A partir da psiquiatrização do degenerado e dos postulados do organicismo de Kraepelin, os psiquiatras passaram a compactuar com as ideias eugênicas instituídas por Francis Galton. Na Europa, nos Estados Unidos e no Brasil, as sociedades eugênicas, em sua grande maioria, eram dirigidas por médicos. 
A teoria da degeneração e suas implicações no Hospital de Doenças Nervosas e Mentais.

É importante ressaltar que esse aporte teórico possibilitou aos psiquiatras um novo campo de atuação através da justificativa de que as causas dos transtornos mentais eram decorrentes da constituição das pessoas e do caráter hereditário. Essa observação é significativa para compreendermos o diagnóstico Episódio Delirante dos Degenerados, tão abonado pelos psiquiatras nos hospícios europeus e brasileiros especialmente nas primeiras décadas do século XX. Afirma Carrara que "a degeneração, enquanto uma das formas de alienação mental, tornava o conceito fluido e abrangente que poderia equacionar em seus termos uma gama muito grande de comportamentos que não havia sido claramente patologizados" (CARRARA, 1998, p. 95). Dessa maneira, o enclausuramento das pessoas avaliadas degeneradas atendia aos reclamos de alguns setores da sociedade, especialmente da elite médica e jurídica, que propunham sanear os espaços urbanos restrigindo a presença daqueles que, de alguma forma, perturbavam a paz social e ameaçavam o "enfraquecimento da raça".

Assumindo feições ecléticas, os trabalhos apresentados pelos acadêmicos nas faculdades de medicina do Brasil seguiram a orientação metodológica baseada na concepção de degenerescência de Morel, Magnan e na teoria organicista de Kraepelin. Nos primeiros anos da República (1890), o Hospício Pedro II recebeu o nome Hospício Nacional de Alienados e sua administração foi desvinculada do hospital da Santa Casa de Misericórdia, ficando sob a tutela do Estado. Em 21 de junho do mesmo ano, foi aprovado o regulamento para a Assistência Médico-Legal do Hospício Nacional dos Alienados. Em 1903, através do decreto no 508, de 22 de dezembro de 1903, a Assistência aos Alienados foi reorganizada na capital da República e serviu de exemplo para que outros estados a implementassem (VENANCIO; BRAGA, 2016, p. 18). É importante ressaltar o 10 Regulamento do Hospício de Alienados que organiza os serviços administrativos e sanitários do Hospício Nacional que passou a contar com:

a) o diretor do Hospício Nacional; b) alienistas; c) adjunto; d) pediatra; e) médico dos pavilhões de moléstias infeciosas intercorrentes; f) chefe dos serviços cinesioterápicos; g) internos; h) pharmacêutico; i) ajudante do pharmacêutico; j) inspetores; k) enfermeiros; e, l) guardas.No quadro de pessoal do Serviço Econômico Interno havia: a) o administrador do Hospício Nacional; 
b) o pessoal da despensa, cozinha, refeitórios, lavanderia, oficinas, jardim e horta; c) o pessoal da secretaria; d) o arquivista; e) o porteiro; e f) o contínuo. Sobre a organização dos trabalhos, nos dias uteis o serviço começava ás 10 horas da manhã e terminava às 3 da tarde, podendo a hora do expediente ser prorrogada pelo diretor ou pelo primeiro escriturário, quando os trabalhos o exigissem. Nas Colônias: um director-medico, um alienista, um adjunto, um pharmaceutico, um almoxarife, um primeiro e um segundo escripturarios. (COELHO FILHO, 1977, p 73-82)

Nessa época, o sistema de assistência psiquiátrica permitiu que fossem reformados e criados inúmeros hospícios através de pesquisas e novas tecnologias - laboratórios e serviços médico-legais, além de uma maior ingerência por parte dos psiquiatras junto ao Estado e à família. Magali Engel comenta esse novo olhar dos psiquiatras frente à loucura:

A noção de doença mental tende a ser definida dentro de limites cada vez mais amplos, abrangendo assim, uma série de sintomas que, imperceptíveis aos olhares destreinados, só poderiam ser completa e corretamente apreendidas pelos especialistas. Nesse sentido, a doença mental tornar-se-ia paulatinamente distante e diferenciada da loucura, que comumente associada ao delírio - e, portanto, a uma visibilidade imediata - seria cada vez mais freqüente definida pelos alienistas apenas como um tipo de doença mental. (ENGEL, 2001, p. 108)

Ainda no início do século XX, a Sociedade Brasileira de Neurologia, Psiquiatria e Medicina Legal foi fundada durante uma reunião na Academia de Medicina, no Rio de Janeiro, em 17 de novembro de 1907. Foi a primeira associação médica brasileira a buscar a especialização da "medicina mental", colocando em debate questões científicas e assistenciais que estruturaram o que passou a ser chamado de psiquiatria.

Um ano após a sua criação, a Sociedade, com a presença dos médicos Juliano Moreira, Afrânio Peixoto, Carlos Eiras, Austregésilo e Henrique Roxo, aceitou a incumbência de apresentar um projeto de classificação dos transtornos mentais que pudesse servir de base às estatísticas dos manicômios judiciários. Entretanto, por motivos desconhecidos, o plano desses psiquiatras não sofreu continuidade até que, em 1910, Juliano Moreira retomou o tema atendendo a uma solicitação da Repartição Geral de Estatística. Desse trabalho, originou-se a classificação da Sociedade Brasileira de Psiquiatria, Neurologia e Medicina Legal 
que seguia a estrutura original da classificação de Kraepelin. É importante ressaltar que esse discurso médico não chegou à maioria das capitais brasileiras, tendo em vista a precariedade de suas estruturas manicomiais e, em muitos casos, a total ausência de qualquer assistência psiquiátrica nos hospícios.

O saber médico sobre a cidade, produzido nas Sociedades, Academias e nas Faculdades de Medicina, incluía uma preocupação com as "doenças mentais" e físicas que atingia a população dos principais centros urbanos brasileiros. Para alguns setores da sociedade e da congregação médica, era importante uma intervenção enérgica no sentido de afastar os loucos e os degenerados, alguns deles personagens famosos das ruas, tendo em vista seus comportamentos inconvenientes e atitudes, por vezes, violentas.

Em 1916, Afrânio Peixoto afirmou que a degeneração era uma ideia aceita e empregada de forma exagerada, pelos psiquiatras, porém havia se tornado uma página virada na história da psiquiatria: “Tudo era degenerescência. Os italianos, psiquiatras e criminalistas, levaram ao exagero e absurdo. Os estigmas de degeneração foram pacientemente catalogados, formando vasta coleção" (PEIXOTO, 1916, p. 208-209). Apesar das observações de Afrânio Peixoto de que o entusiasmo inicial dos psiquiatras pela ideia da degeneração havia passado, inúmeros foram os médicos, juristas e intelectuais que continuaram adeptos fervorosos dessa teoria associada aos postulados lombrosianos, acreditando que para um caso de degeneração nervosa era indispensável observar as deformações anatômicas e os problemas de ordem fisiológica, pois tais anormalidades no organismo seriam diagnosticadas como "estigmas da degeneração". Entretanto, ainda em sua obra Psicopatologia Forense, o próprio Afrânio enumerou nove aspectos que considerava como "estigma somático da degeneração" (PEIXOTO, 1916, p. 231-233). Nos anos 1920, o diagnóstico do degenerado era encontrado de forma significativa em inúmeros prontuários do H.D.N.M. sob a direção de Ulysses Pernambucano (1924-1926) que, posteriormente, fora médico atuante no Hospital, conforme veremos no decorrer do texto.

Durante a gestão de Rodrigues Alves, o Dr. Antonio Austregésilo integrou a equipe do Dr. Juliano Moreira que havia assumido a Diretoria de Assistência aos 
Alienados. Em 1912, foi nomeado professor da recém-fundada cátedra de Clínica Neurológica da Faculdade de Medicina do Rio de Janeiro. Médico influente, publicou um livro sobre Clínica Neurológica, escrito em 1917. Em seus escritos apresentou inúmeros casos. Ao realizar o exame somático no paciente C.G.S.F., sexo masculino, 22 anos de idade e diagnosticado portador de "Síndrome Histeróide", remeteu-se inúmeras vezes aos estigmas da degeneração: "Fisionomia indiferente, estigmas físicos de degeneração, orelhas pequenas e mal conformadas, dentes viciosamente implantados precocemente cariados e língua sabugosa" (AUSTREGESILO, 1917, p. 235).

Outro paciente examinado pelo Dr. Austregésilo e avaliado como portador de mimetismo - atitudes de imitação de pessoas e animais - exibia um acentuado grau de degeneração, segundo o neurologista: "tratava-se de um imbecil de cor preta chamado Tomás - degenerado inferior - que apresentava estigmas degenerativo muito evidente, para o lado da face, da cabeça e dos pés". Conforme o médico, esse paciente quando estava alegre costumava imitar o latido de um cachorro que sempre o acompanhava". (AUSTREGÉSILO, 1917, p. 280). Nos seus registros, percebemos de forma explícita o quanto as teorias da degeneração de Morel e Magnan estavam presentes e como o médico tenta articular a psiquiatria da época à neurologia.

No Brasil, nas décadas de 10 e 20 do século XX, as ideias eugênicas de Francis Galton (1822-1911) passaram a exercer grande influência no meio médico e intelectual, principalmente entre os higienistas e psiquiatras que acreditavam poder acabar com a "degeneração moral e racial" da população brasileira. A conviç̧ão dos eugenistas era de que, tão logo seus postulados fossem compreendidos e postos em práticas, essa "estranha noção de ciência" se tornaria a esperança e o remédio para os males que tinham origem fundamentalmente nas diversas constituições hereditárias dos brasileiros. O Farmacêutico e médico Renato Ferraz Kehl (1889-1974) concentrou grande parte de sua vida para a implantação da eugenia no país, tendo sido responsável pela criação das primeiras instituições eugênicas no Brasil, além de ser escritor de inúmeras obras que propagandeavam a eugenia no meio intelectual, médico e político. 
Nos anos de 1920, o ideal eugênico continuava a seduzir uma parcela significativa dos psiquiatras brasileiros. No Rio de Janeiro, no ano de 1923, foi criada, pelo psiquiatra Gustavo Riedel, a Liga Brasileira de Higiene Mental - LBHM - que congregava, além de médicos, principalmente psiquiatras, educadores, juristas, empresários e políticos brasileiros. A entidade era reconhecida como de utilidade pública e recebia subvenção federal para a execução de suas atividades. Para divulgar suas idéias e defender o "saneamento racial", a liga mantinha uma revista própria, intitulada “Archivos Brasileiros de Higiene Mental”, que começou a circular no ano de 1925. Os debates dos seus integrantes, muitas vezes calorosos, estavam diretamente ligados a questões eugênicas: combate ao alcoolismo, através da programação anual de semanas antialcoólicas; esterilização compulsória de degenerados e criminosos, considerados reprodutores perigosos; exame pré-nupcial; segregação de pessoas por diversos motivos eugênicos; eugenia infantil e seleção e orientação profissional com o objetivo de racionalização do trabalho. Segundo Nancy Leys Stepan, a Eugenia não foi "unitária e não pode ser indiscriminadamente apreendida. O estudo da Eugenia na América Latina revela alguma das forças contraditórias que atuavam dentro do movimento e as formas diversas como poderiam ser absorvidas" (STEPAN, 2005, p. 11).

O Brasil foi um dos primeiros países a desenvolver, na América do Sul, o movimento eugênico, a reunir grande número de adeptos e um dos que mais teve sucesso no processo de institucionalização da eugenia. Basta lembrar que a primeira sociedade eugênica criada pelos brasileiros, a Sociedade Eugênica de São Paulo, foi fundada ainda nos anos 1910 e contou com nada menos que 140 membros, a maioria formada pela elite médica do país. Entre os seus integrantes estavam figuras prestigiadas, como Afrânio Peixoto, Arthur Neiva, Juliano Moreira, Antonio Austregésilo, Fernando Azevedo e Belisário Penna, Monteiro Lobato e o senador Alfredo Ellis. O movimento eugênico também foi responsável pela realização do primeiro Congresso Brasileiro de Eugenia e pela publicação do Boletim de Eugenia, periódico editado entre 1929 e 1934 (SOUZA, 2016, p. 293).

É importante ressaltar que a LBHM funcionou como ponto irradiador para a criação de outras associações direcionadas à higiene mental em várias capitais 
do Brasil. Em Pernambuco, no início dos anos 30, o Serviço de Higiene Mental (SHM) foi criado e tinha como finalidade maior acompanhar os pacientes do Hospital de Alienados em suas residências através de visitas periódicas de monitoras sempre que ocorressem indícios de "anormalidades". Era intenção dos dirigentes do SHM realizar relatórios que possibilitassem organizar em fichas informações detalhadas especialmente sobre o comportamento no meio familiar e a conduta do indivíduo na sociedade. No estatuto da LBHM, capítulo primeiro, artigo 1, alínea d, a aproximação com os postulados eugênicos é definida como : "realização de um programa de Higiene Mental e de Eugenética no domínio das atividades individual, escolar, profissional e social".

Essas diretrizes foram confirmadas numa conferência realizada por Juliano Moreira, presidente de honra da Liga, em dia 26 de abril de 1928, que discorreu sobre os "Fatores Hereditários em Psiquiatria." No início da sua palestra, exposta pelo psiquiatra Ernani Lopes, relatou os avanços sobre a temática nos centros de pesquisas da Suécia, Holanda, Inglaterra, dos Estados Unidos e especialmente da Alemanha, na Clínica Psiquiátrica de Munique, criada por Kraepelin e sob a direção de Ernest Rudin, psiquiatra e fundador do movimento alemão de higiene racial. Em seguida, realizou comentários sobre a predisposição hereditária de famílias de epiléticos e esquizofrênicos. Na última parte da sua conferência, Juliano Moreira fez uma longa explanação a respeito da "profilaxia dos distúrbios psíquicos hereditários", enfatizando a necessidade de evitar a reprodução de "anormais" alienados, delinquentes, alcoólicos e degenerados "em proveito da preservação da raça humana".

Mencionou a esterilização como uma forma rápida e já utilizada em vários países europeus e nos Estados Unidos, como também a criação de leis reguladoras, através de um certificado médico pré-nupcial, para impedir a "união de indivíduos susceptível de procriar elementos indesejáveis." Por fim, alertou a importância de se combater os perigos externos, como as doenças responsáveis pela proliferação da "herança mórbida": alcoolismo, sífilis e a tuberculose e pela "transmissão das taras hereditárias" (ARCHIVOS BRASILEIROS HYGIENE MENTAL, 1929, p. 29-34). Para os membros da LBHM, era importante intervir na sociedade afastando os "elementos indesejáveis" e transgressores das normas morais através do enclausuramento em hospícios e prisões. 


\section{A institucionalização do Hospício em Pernambuco}

Nas cidades do Brasil, as pessoas consideradas loucas eram, muitas vezes, abandonadas por seus familiares e enclausuradas em asilos, delegacias de polícia e presídios. No Recife, muitas delas foram internadas no Hospital de Doenças Nervosas e Mentais ou na Casa de Detenção. Por outro lado, alguns "tipos populares", considerados "loucos de rua", foram aceitos pela população e continuaram a sua vivência pelas ruas da cidade, sendo, no entanto, motivo de deboches e gracejos por parte de crianças e adultos, muitas vezes com um certa dose de sadismo (FERRAZ, 2000, p. 233). Com hábitos "estranhos" e vestimentas exóticas, vagavam pelos logradouros pedindo esmolas nas portas das igrejas e nos estabelecimentos comerciais e públicos. Pelas suas excentricidades, tornaram-se, algumas vezes, notícia dos jornais. Quando reagiam com algum tipo de agressão ou faziam uso de palavras "indecentes", "ameaçavam” a convivência com a população e dessa forma o fio de tolerância era partido rapidamente. Alguns foram perseguidos, excluídos do convívio social e encaminhados aos hospícios. O escritor memorialista Mário Sette descreve alguns desses personagens que fizeram parte da paisagem urbana do Recife das últimas décadas do século XIX e início no XX, a exemplo de Bode Ioiô, Maracujá de Gaveta, Barrinhos, Tinisco, Madame Papoula e Cariri (SETTE, 1978, p. 316).

Em Pernambuco, o Presidente de Província, Henrique Pereira de Lucena, decidiu construir o Hospício dos Alienados do Recife. Victor Fournié, projetista da obra, adotou o Sistema Pavilhonar, considerado até então o padrão arquitetônico hospitalar mais moderno da época. Inaugurado em primeiro de janeiro de 1883, recebeu, mesmo quando não se encontrava totalmente concluído, os 87 pacientes do hospital da Santa Casa de Olinda: "47 homens e 40 mulheres". Desde a sua inauguração, o hospital passou por períodos de crises graves, tendo em vista a falta de verbas, de pessoal médico, de higiene em suas instalações e o aumento crescente de sua população interna, uma vez que o hospício recebia doentes de todas as regiões de Pernambuco e de outros estados do Nordeste. No mesmo ano de sua inauguração, o asilo já apresentava sérios problemas estruturais. Em relatório apresentado ao Presidente da Província, o Dr. Pedro 
Lobo Moscoso, Inspetor de Saúde Pública, fez duas críticas à precariedade do sistema de esgoto e à qualidade da água fornecida aos doentes:

A água extraída dessa grande cacimba é um pouco turva, de cheiro e gosto desagradável [...] a respeito das latrinas, é escusado falar porque já se sabe que sem muita água não se pode evitar o mau cheiro... A um mês e meio que se fez a mudança dos doentes e já se sente o mau cheiro em quase todos os compartimentos. (RELATÓRIO, 1883, p. 67)

Segundo o médico, o prédio foi levantado para receber 600 doentes, além dos empregados, serventes e das irmãs de caridade, porém a constituição de seu esgoto e o abastecimento da água não foram pensados. Os dejetos fecais eram lançados num chamado "poço absorvente ou sumidouro" que se localizava perto de um outro, com água aparentemente melhor. Era por esse motivo que a água utilizada coletivamente para higienização, consumo e preparação de alimentos era retirada de um poço mais afastado do edifício porém, ainda assim, apresentava-se turva, com cheiro e gosto desagradáveis em virtude do lodo formado pelas folhas que caíam das árvores frondosas em seu entorno. Haja vista essa situação, os empregados mandavam também buscar água da Companhia do Beberibe, por ser própria para consumo. Diante dessa dificuldade de abastecimento de água e da falta de funcionários para sua limpeza, as latrinas exalavam um cheiro fétido em quase todos os compartimentos. O médico criticou, ainda, a disposição das celas e a reutilização das grades de ferro que estavam no Hospício de Olinda com a finalidade de trancafiar os "loucos furiosos". ( MOSCOSO, 1883, p. 68-69)

A terapêutica se constituía ao emprego de banhos, camisa de força, reclusão nos calabouços, uso de medicamentos à base de brometo de potássio, hidrato de cloral, amileno, sulfonal, quina e de sedantes, como o ópio e a morfina. A quebra do regime disciplinar do hospício poderia implicar duras medidas contra os internos. Dessa forma, os meios terapêuticos, muitas vezes, confundiam-se com mecanismos de castigos. O Art. 38 do primeiro Regulamento estabelecia que, mediante autorização do facultativo, poderiam ser empregados os seguintes métodos punitivos: reclusão solitária de até dois dias; diminuição de dieta alimentar por um dia; privação de visita, passeios e quaisquer outros recreios, 
inclusive o uso de tabaco; colete de força, com ou sem reclusão; cadeira de força e banhos de emborcação aplicados somente na presença de um dos facultativos. (MOSCOSO, 1883, p. 75-84)

No final do século XIX, dotado de péssimas condições de higiene e de espaços onde conviviam misturados crianças, adultos e portadores de doenças infectocontagiosas, o hospício tão logo se transformou num verdadeiro depósito de doentes, com elevada taxa de mortalidade. Segundo um relatório apresentado pela Junta Administrativa da Santa Casa de Misericórdia, em 1891, ocorreram 251 óbitos, o que corresponde a $40 \%$ da totalidade dos pacientes internados no hospício neste ano (MOSCOSO, 1891, p. 91)

Após a proclamação da República, a direção da instituição foi entregue a dez freiras italianas da Congregação das Filhas de Santana que, juntamente com o provedor da Santa Casa, promoveram uma reformulação no quadro de pessoal. O capelão Frade Augusto da Imaculada Conceição foi demitido e substituído por um padre italiano. Trocaram também o diretor, o amanuense e os enfermeiros. Sem dominar a língua portuguesa, as freiras logo encontraram sérias dificuldades para administrar o hospício que continuou em decadência e sem condições de proporcionar um tratamento adequado aos pacientes. Em pequeno número, os médicos (facultativos clínicos) estavam subordinados às religiosas e ao mordomo e quase sempre se encontravam à margem das questões de ordem administrativa. Em muitos casos, até a orientação do tratamento terapêutico sofreu a interferência por parte das irmãs de caridade. Além da ignorância e da violência dos enfermeiros, os ineficientes meios terapêuticos se restringiam ao emprego de camisa de força, reclusão em calabouços e ao uso de poucos e ineficazes medicamentos.

Após a direção do Dr. Inácio Firmo Xavier, o comando do hospício foi entregue ao Doutor Ermínio Coutinho que, em virtude de seu falecimento em 06 de abril de 1904, foi sucedido pelo Dr. Joaquim Loureiro, auxiliado pelos médicos Dr. Constâncio Pontual, Fernando Lisboa Coutinho e Teófilo de Holanda Cavalcanti. Nesse período, foram acrescidos ao corpo hospitalar do hospício, os médicos recém-formados Alcides Codeceira, Teodorico Padilha e Souto Maior; A rotina do hospital foi um pouco modificada quando se introduziram os serviços 
de eletroterapia e instituída a hidroterapia e a clinoterapia em um pavihão destinado exclusivamente para o tratamento de repouso no leito, além de outros pequenos melhoramentos (COELHO FILHO, 1977, p. 87-88). Apesar da figura do médico-diretor substituir as irmãs da caridade no controle da administração, o hospício continuou dotado de condições insalubres e com um corpo de enfermeiros truculentos e pouco habilitados. As queixas eram constantes contra as condições do hospício sob a tutela do Provedor da Santa Casa de Misericórdia. Embora fossem frequentes as lamentações relacionadas à falta de verbas, os "irmãos filantrópicos" pareciam estar mais preocupados em manter as vantagens proporcionadas pelo cargo e poucos "enxergavam" as condições em que viviam os internos do Hospício de Alienados. Desde o Brasil Colônia e o Império, o cargo de Provedor das Santas Casas era um dos mais disputados pela "elite".

Não obstante algumas inovações na década de 20 , as instalações do Hospício de Alienados ainda se encontravam num estado de extrema precariedade. Os pacientes encarcerados e amontoados viviam numa situação de promiscuidade, solidão, desespero e eram submetidos à terapêutica disponível na época. Em dezembro de 1921, foi aceito o pedido de exoneração do Dr. Joaquim Loureiro e do seu filho, o também médico Luiz Loureiro, e a direção do hospício foi entregue ao Dr. Alcides Codeceira, primeiro catedrático da Clínica Psiquiátrica da Faculdade de Medicina do Recife.

Respaldada pelas autoridades governamentais e pela sociedade, a psiquiatria institucional encontrou um profícuo campo de atuação. A grande maioria dos considerados loucos eram indigentes e viviam em situação de penúria. Com uma clientela formada quase exclusivamente por pessoas pobres, o Hospício de Alienados revelou sua função segregadora. As suas enfermarias eram anti-higiênicas, a alimentação e os vestuários insuficientes, faltava médico e medicamento (COELHO FILHO, 1977).

\section{A degeneração nos prontuários no Hospital de Doenças Nervosas e Mentais}

Durante a sua gestão, o governador Sérgio Loreto (1922-1926), em 5 de fevereiro de 1923, baixou um ato pelo qual a Diretoria de Hygiene e Saúde Pública 
passou a se chamar Departamento de Saúde e Assistência, subordinado diretamente ao executivo. Unificando os serviços de higiene do Estado, entregou à Comissão de Profilaxia Rural (órgão do Governo Federal) a sua administração em Pernambuco. Para essa iniciativa, convidou o médico Amaury de Medeiros para o cargo de diretor do Departamento de Saúde e Assistência e, ao mesmo tempo, para chefiar os Serviços de Saneamento e Profilaxia Rural. Na época, o doutor Medeiros, atendendo a sugestão de Ulysses Pernambucano, enviou à Comissão de Finanças da Câmara um projeto transferindo para o Estado os encargos com a administração do Hospício dos Alienados e de alguns outros hospitais do Recife. Tal proposta foi aprovada e recebeu a imediata adesão do corpo médico. No ano de 1924, o Hospício de Alienados, integrado a uma sessão do Departamento de Saúde e Assistência, foi transformado em H.D.N.M., assumindo a sua direção o doutor Ulysses Pernambucano, ardoroso discípulo de Juliano Moreira e adepto de novo modelo de assistência psiquiátrica em que o médico intervém dentro e fora do hospício. Durante o período que exerceu o cargo de diretor, criou o Instituto de Psicologia, em 1925, com a colaboração da psicóloga Anita Pais Barreto (ROSA, 2001, p. 74), lecionou na Faculdade de Medicina do Recife, dirigiu a Escola Normal até o ano de 1927, além de atuar de forma efetiva na Sociedade Pernambucana de Medicina e em sua clínica particular.

Figura 1 - O Calabouço

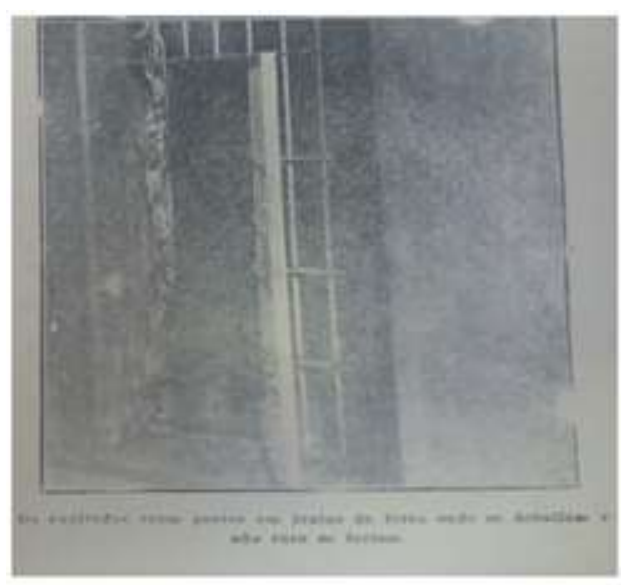

Figura 2 - Pavilhão de Observação

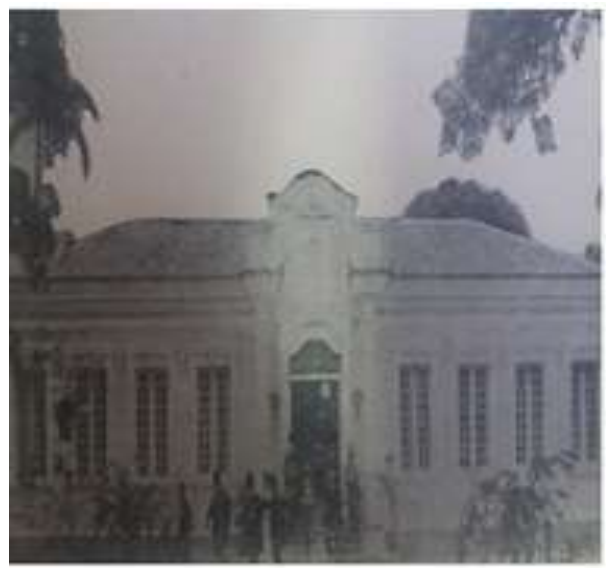

Fonte: MEDEIROS, Amaury. Saúde e Assistência: Doutrina, experiências e realizações, 1923-1926, Recife: [s.n.], 1926.

Em sua gestão de dois anos, efetivou importante reforma nas instalações físicas do prédio, construindo doze quartos para pensionistas, substituiu a 
instalação elétrica, mudou o piso dos corredores e aboliu os calabouços (Figura1), onde eram colocados os considerados "furiosos" ou aqueles que rejeitavam se submeter com frequência às normas do hospício. Introduziu melhoramentos na observação e na pesquisa psiquiátrica e aplicou novos procedimentos terapêuticos. Iniciou a edificação do Pavilhão de Observação, P.O. (Figura 2) o Pavilhão Anatômico, a portaria, o muro, o gradil e o portão de entrada, bem como o Pavilhão das Duchas, além disso, realizou a pintura geral do prédio (COELHO FILHO, 1977, p. 114). No dia 17 de março de 1925, foi colocada a pedra fundamental do Pavilhão de Observação no H.D.N.M. A solenidade contou com a presença do governador do estado e secretários, outras autoridades estaduais e municipais e representantes da classe médica do Recife, além dos médicos do hospital. $\mathrm{Na}$ ocasião, discursaram os doutores Amaury de Medeiros, Alcides Codeceira e o diretor Ulysses Pernambucano que destacou a importância da criação do P.O., tendo em vista que os exames dos "alienados" eram realizados na Casa de Detenção (Diário de Pernambuco. 17/3/1925). Enquanto a sua edificação não havia sido concluída, o Serviço de Observação ocorria em duas enfermarias do hospital. Essa transferência possibilitou um maior vínculo com o ensino prático de Clínica Psiquiátrica dos estudantes da Faculdade de Medicina no H.D.N.M.

$\mathrm{Na}$ época, os prontuários se tornaram cada vez mais complexos, trazendo uma série de informações sobre os pacientes até então inexistentes. Com essas mudanças fica evidente que a psiquiatria em Pernambuco passou a se interessar mais pelos aspectos regulamentar e administrativo da instituição. Quando ocorreu a transformação do Hospício de Alienados em Hospital de Doenças Nervosas e Mentais, em 1924, juntamente às inovações promovidas no sistema asilar, o número de pessoas internadas aumentou consideravelmente, chegando a duplicar a sua população em apenas sete anos. Além dessas modificações, as novas concepções europeias sobre os transtornos mentais favoreceram a internação de novos personagens que vão habitar os labirintos do H.D.N.M. Como instituição hospitalar de referência no Estado, os delegados da capital e do interior, além de familiares, passaram a encaminhar pessoas consideradas "loucas".

Anteriormente, os formulários para exame após a admissão do paciente seguiam o mesmo modelo implantado em quase todos os hospícios do Brasil. 
As exigências para o seu preenchimento atendiam às recomendações inscritas no Decreto n 6440, de 03 de março de 1907, sobre o Serviço Policial do Distrito Federal: Exame médico-legal dos alienados. Depois de assumir o H.D.N.M., Ulysses Pernambucano ampliou de forma detalhada as informações que passaram a constar nos prontuários.

Algumas fotografias são muito emblemáticas para percebemos a extensão das reformas empreendidas por Ulysses Pernambucano no H.D.N.M., como a criação da sala de hydroterapia:

Figura 3 - Banheiras

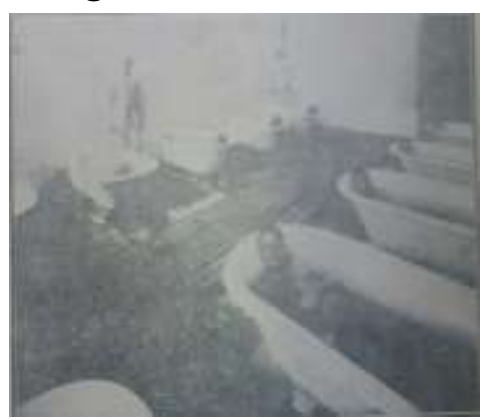

Fonte: MEDEIROS, Amaury. Saúde e Assistência: Doutrina, experiências e realizações, 1923-1926, Recife: [s.n.], 1926.
Figura 5 - O Canhão
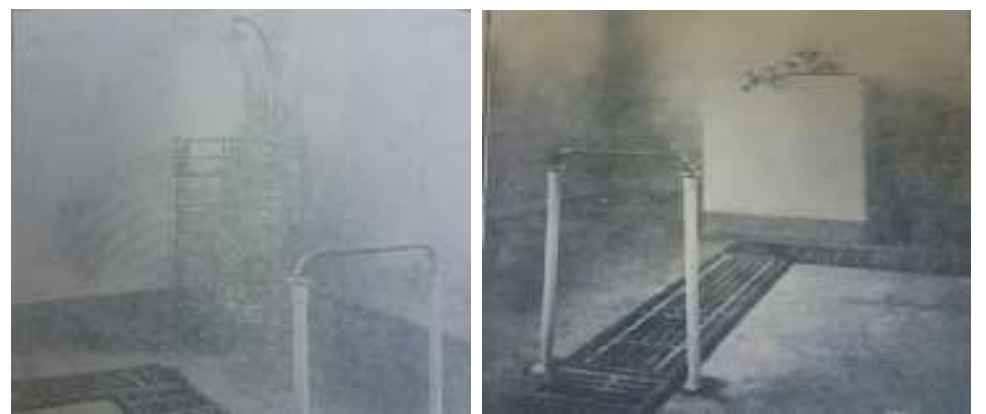

(1)

Na figura 3, os pacientes passavam horas imóveis dentro das banheiras com água fria deixando só a cabeça do lado de fora, sob o olhar vigilante dos enfermeiros; Na figura 4, eram colocados em duchas circulares, também denominadas "gaiolas", onde passavam um bom tempo, em pé, recebendo jatos de água por todo o corpo; Na figura 5, alguns pacientes eram submetidos à violência da ducha fria frontal, também designada canhão de água, o que resultava algumas lesões nos pacientes. Atribuía-se aos banhos frios efeitos analgésicos, antiflogísticos, sedativos e hipnóticos. Essas práticas que atuavam diretamente na superfície corpórea eram usadas com frequência nos mais exaltados, com o objetivo terapêutico de submeter os considerados portadores de doenças mentais às regras estabelecidas pelos psiquiatras. Além dessa terapêutica, era aplicada a clinoterapia, “repouso forçado", em que o paciente era colocado num leito imobilizado, passando horas. Eram prescritas ainda medicações tônicas (derivadas do ferro, sais de cobre, brometos e quinina).

O Boletim de Higiene Mental, publicado em dezembro de 1933, conforme tabela exposta abaixo, exibe o quantitativo de adultos e crianças no H.D.N.M. 
Além dessa importante informação, a tabela apresenta um total de 236 crianças e adolescentes, de ambos os sexos, internadas em sua grande maioria como portadores de psicose epilética e episódio delirante de degenerado. O H.D.N.M. também recebia crianças abandonadas vindas de outros hospitais e algumas do interior do estado. É o caso de M.L.F, de cor branca, 12 anos de idade, que foi encaminhada pelo Diretor do Hospital Oswaldo Cruz e diagnosticada como portadora de Epilepsia. Deu entrada no dia 5 de janeiro de 1927 e faleceu em 12 de dezembro do mesmo ano (LIVROS DE PRONTUÁRIOS DO PAVILHÃO DE OBSERVAÇÃO E DO H.D.N.M., 1927).

\begin{tabular}{|c|c|c|c|}
\hline \multicolumn{4}{|c|}{$\begin{array}{c}\text { Entrada de adultos e de crianças no Hospital de } \\
\text { Doenças Nervosas e Mentais ( 1924-1930) }\end{array}$} \\
\hline ANO & $\begin{array}{c}\text { TOTAL DE } \\
\text { DOENTES }\end{array}$ & NÚMERO DE CRIANÇAS & PORCENTAGEM \\
\hline 1924 & 670 & 19 & $2,4 \%$ \\
\hline 1925 & 767 & 30 & $3,9 \%$ \\
\hline 1926 & 730 & 34 & $4,6 \%$ \\
\hline 1927 & 1.070 & 34 & $3,3 \%$ \\
\hline 1928 & 1.023 & 50 & $3,8 \%$ \\
\hline 1929 & 1.141 & 35 & $3,06 \%$ \\
\hline 1930 & 1.128 & 34 & $3,05 \%$ \\
\hline
\end{tabular}

Fonte: Boletim de Higine Mental, 1933, p. 3.

Nas primeiras décadas do século XX, a epilepsia era considerada pelos médicos uma "doença mental de fundo degenerativo, revelada por uma autointoxicação permanente e uma excitabilidade fácil dos centros corticais e medulares que promovem modificações fundamentais de caráter e descarga motoras, sensoriais, psíquica de insólita violência (crise ou ataques epiléticos)". Segundo Afrânio Peixoto, eram dotados de estigmas físicos de degeneração e possuidores de um caráter "móvel, suspeito, desconfiados, dissimulados, irritável, impulsivo, egoísmo, duplicidade, teimosia, crueldade”. Estigmatizados, eram consideradas pessoas passivas de adotarem "manifestações de periculosidade". Afrânio Peixoto ressaltava que a justiça e a medicina deveriam ficar atentas às 
reações perigosas provocadas pela epilepsia à pessoa portadora da "doença, de sua família, e até da sociedade em geral” (PEIXOTO, 1916, p. 261)

Margarida de Souza Neves, ao analisar artigos sobre epilepsia publicados na revista Arquivos Brasileiros de Psiquiatria, Neurologia e Medicina Legal, em 1915 e 1918, revela uma aproximação, pela ciência médica no Brasil, entre a epilepsia e a propensão à violência e ao crime. Por outro lado, o seu texto apresenta histórias de vida de pacientes, cinco mulheres e de um homem, diagnosticados como "epiléticos" no Hospital Nacional de Alienados. (NEVES, 2010, p. 293-311).

Outro caso significativo é o de S.F.S., de cor "parda", com a idade de 16 anos, natural de Pernambuco e solteiro. Foi encaminhado pelo Pavilhão de Observação para o HDNM no dia 13 de novembro de 1929, com Episódio Delirante dos Degenerados. Em seu prontuário, há um resumo do atestado infomando que S.F.S. tinha uma irmã acometida de diversas crises de "loucura". Segundo os psiquiatras, o "doente" declarou que ouvia palavras e que era fortemente perseguido por espíritos que the apareciam com frequência. Encerrando suas observações, o médico declarou que o paciente era praticante do espiritismo. S.F.S. recebeu alta no dia 10 de outubro de 1920, ou seja, quase um ano depois da sua internação. Em pesquisa realizada na documentação, constatamos que a associação entre loucura e "baixo espiritismo" foi acentuada nas duas décadas posteriores (LIVROS DE PRONTUÁRIOS DO PAVILHÃO DE OBSERVAÇÃO E DO H.D.N.M., 1929).

Com o movimento de outubro de 1930, ocorreram mudanças na política institucional do país. Em Pernambuco, assume o poder como interventor, Carlos de Lima Cavalcanti. Nesse período, novas estratégicas foram pensadas como forma de controlar e reprimir qualquer tipo de manifestações contrárias às novas diretrizes do projeto de construção do Estado Nacional. Nesse momento, o papel da polícia se fez importante no sentido de impor a ordem e a "paz social". Em Pernambuco, foi criada a Secretaria de Segurança Pública (SSP), em junho de 1931, que substituiu a Repartição Central de Polícia e, em novembro do mesmo ano, foram instituídas as Delegacias Auxiliares. A nova instituição tinha ligação 
direta com o Palácio do Campo das Princesas e sua estrutura ocupava um quadrante de prédios situado na Rua da Aurora.

Em novembro de 1935, com o levante comunista, foi decretada a Lei se Segurança Nacional e, em 23 de dezembro, criada a Delegacia de Ordem Política Social (DOPS), que tinha como objetivo realizar investigações, exercer censuras e reprimir aqueles que fossem de encontro às novas diretrizes sociais e politicas do Estado. Com o aparelhamento dos órgãos da polícia nos anos 30, os adeptos do espiritismo e dos cultos afro-brasileiros continuaram reprimidos, apesar de Ulysses Pernambucano intermediar o funcionamento de alguns terreiros que seguissem a orientação do Serviço de Higiene Mental criado por ele. Após a prisão de Dr. Ulysses, em 1935, na Casa de Detenção do Recife por sessenta dias, os cultos afro-brasileiros passaram a sofrer uma violenta perseguição policial, especialmente durante o Estado Novo na interventoria de Agamenon Magalhães. A perseguição ao médico, pelos órgãos de segurança, perdurou até a sua morte, por infarto, ocorrida na cidade do Rio de Janeiro em 05 de dezembro de 1943.

A.A.C., de cor "preta", com a idade de 14 anos, pernambucana, solteira e doméstica foi encaminhada pela polícia no dia 12 de março de 1929. Com relação aos antecedentes sociais, consta que era adepta do espiritismo e o praticava com certa frequência. Em seu exame mental foi observado pelos psiquiatras que em alguns momentos era agressiva, em outros se comportava com profunda tristeza. Depois de serem observados os aspectos somáticos, foi diagnosticada com degenerescência episódio delirantes.

Observamos que o diagnóstico atribuído pelos psiquiatras procurava quase sempre relacionar os "problemas mentais" à "hereditariedade patológica". É o caso de J.S. de cor branca, nascida no Recife, com 12 anos de idade, que foi encaminhada pela polícia. Deu entrada no Pavilhão de Observação no dia 08 de março de 1929, depois de quatro dias foi internada no H.D.N.M. com o diagnóstico de debilidade mental por alcoolismo. Em seus antecedentes hereditários foi anotado que seus pais eram alcoólatras, fato que haveria influenciado seu diagnóstico. Em seu exame mental, foi ressaltado pelos médicos o vocabulário "sem pudor e obsceno". De temperamento agitado e inquieto, "seus reflexos pupilares" não apresentavam reação à luz; essas observações levaram os 
psiquiatras a diagnosticarem J.S. como portadora de "estigma degenerativo". Depois de cinco meses de internação no H.D.N.M, recebeu alta no dia 16 de agosto (LIVROS DE PRONTUÁRIOS DO PAVILHÃO DE OBSERVAÇÃO E DO H.D.N.M.1929).

É importante ressaltar que esses dois jovens, encaminhados pela polícia e convivendo no meio de adultos de ambos os sexos, num hospital com superlotação, podem ter sido vítimas de violencia física e sexual. Essa questão ainda não foi devidamente estudada, tendo em vista a falta de informação nos prontuários e na documentação do hospital.

Yonissa Marmitt Wadi, ao analisar a experiências de loucura de algumas mulheres internadas no Hospício de São Pedro, de Porto Alegre, faz uma observação significativa sobre a importância dos prontuários como fonte histórica:

São os prontuários, considerado em seu conjunto ou separadamente, os fornecedores das pintas mais significativas para reconstrução das trajetórias dos internos no HSP. Ainda que tenham sido mediados ou filtrados pelos representantes do saber médico, as suas experiências podem tomar vulto se o historiador atento fizer as perguntas certas, perguntas que tornem reconhecíveis vidas que foram afetadas pelo silê ncio e pela repressão. (WADI, 2006, p. 70-71)

No Pavilhão de Observação do HDNM eram colhidas as primeiras informações dos pacientes para o preenchimento do prontuário: nome, cor, idade, filiação, estado civil, profissão, instrução, naturalidade, residência e o requerimento de entrada e saída. Em seguida, eram submetidos a um minucioso exame em que, primeiramente, eram analisados os seus antecedentes hereditários e colaterais. Durante essa primeira fase, questionava-se sobre a possibilidade de algum familiar, próximo ou distante, ser portador de alguma doença ou traço degenerativo (estado de alienação mental, epilepsia, criminalidade, alcoolismo, sífilis, tuberculose, etc.).

$\mathrm{Na}$ etapa seguinte, os psiquiatras averiguavam se o suspeito de desvio mental havia contraído alguma doença na infância (sarampo, paludismo, catapora, coqueluche, etc.) ou em sua fase adulta. Os médicos também investigavam traumatismos, acidentes, "perversões sexuais", abortos e 
menstruação. Através do Histórico da Doença ou do Exame Mental, avaliavam o grau de inteligência, a habilidade profissional, o caráter (alegre, triste, violento, cruel, colérico, ciumento, avaro, desconfiado, dissimulado, etc.) e alguns hábitos (jogo, indolência, roubo, vagabundagem, brutalidade, etc.), além de outros motivos que os levaram ao Hospital. Outro aspecto apreciado nos exames era a adaptação, a conduta do indivíduo suspeito na enfermaria para com os companheiros, enfermeiros e médicos, além de sua relação com o mundo imaginário (atitudes místicas, depressivas e bizarras).

Procediam-se os exames somáticos por meio da utilização de métodos antropométricos impregnados pelas teorias de Cesare Lombroso (altura, pelos, ossos, assimetria e possíveis anomalias). Observavam-se também os aspectos da pele do rosto, cicatriz, tatuagem, obesidade, digestão, língua, icterícias e as sensibilidades objetiva e sensorial. Reflexos superficiais e profundos, perturbações na palavra, a exemplo da gagueira, também eram examinados pelos psiquiatras. Os exames de fezes, urina e de sangue algumas vezes eram solicitados pelos médicos. Depois dessas observações minuciosas, era realizado o exame psíquico, no qual se avaliava a orientação do paciente no tempo e no espaço, a afetividade, a memória, a imaginação, as vontades, os atos, os delírios e as possíveis alucinações. Por fim, era dado o diagnóstico do paciente e a sua internação no H.D.N.M.

A complexidade dessa documentação reside no fato de que, diferentemente dos prontuários dos hospitais tradicionais em que as informações representam um momento de privacidade médica de um paciente no contexto da doença vivenciada por ele no sistema de saúde, nos prontuários dos hospitais psiquiátricos constavam informações não apenas referentes à evolução da "doença”, mas à história de vida dentro de uma instituição total (RIBEIRO; LAMB; MASCARENHAS, 2018, p. 56). Constatamos, em nossas pesquisas nos prontuários, que muitos pacientes passaram por longos períodos de suas vidas, alguns morreram em completo estado de abandono e outros cometeram suicídio por não suportarem a vivência no hospício. São histórias marcantes de sofrimento de homens, mulheres e crianças, algumas delas sem um diagnóstico conclusivo para sua internação. 
A historiadora Maria Clementina Pereira Cunha chama atenção para a importância das informações contidas nos prontuários e seu valor como fonte histórica para aqueles que se debruçam sobre a história da loucura:

Por outro lado, empreender a análise a partir do hospício significa incorporar aí outras falas que se cruzam: apesar do esforço para aniquilar sua presença e apagar sua voz, os registros do asilo denunciam a presença dos "loucos", resgatam ao menos em parte sua fala e sua experiência, evidenciam sua resistência surda e constante, permitindo o estabelecimento de relações para as quais os historiadores estiveram muito desatentos. (CUNHA, 1996, p. 16)

Para entender melhor o universo dos pacientes internados em hospitais psiquiátricos, Erving Goffman desenvolveu um trabalho de campo de um ano, entre 1955 e 1956, no Hospital St. Elizabeth em Washington, com mais de 7.000 internos. Segundo Goffman, uma boa maneira de aprender algo sobre instituição asilar é se submeter pessoalmente, na companhia de seus membros, à rotina diária das pequenas contingências às quais eles próprios estão sujeitos. Em 1961, publicou: Internados. Ensayos sobre la situación social de los enfermos mentales, resultado de suas observações no Hospital St. Elizabeth (GOFFMAN, 1972). A leitura dessa obra propicou um olhar mais atento na elaboração deste texto.

Na análise dos prontuários, percebemos algumas questões frente a essa situação de perda de autonomia e humilhação dos pacientes. Alguns eram tomados por um estado de total apatia e permaneciam deitados nas enfermarias e no pátio do hospital indiferentes por longos períodos. Nos intervalos entre as refeições, caminhavam de cabeça baixa pelos corredores do hospital. Muitos falavam sozinhos, outros permaneciam no seu total silêncio à espera do tempo passar. No entanto, alguns resistiam à violência imposta pela estrutura manicomial: fugiam, defecavam e urinavam em locais não permitidos, utilizavam "palavrões" para demostrar sua insatisfação, brigavam entre si, agrediam enfermeiras, choravam compulsivamente para irem para suas casas, além de outras reações de descontentamento, a exemplo de suicídios. Ao anoitecer, eram mal acomodados nas enfermarias, onde inexistiam armários individuais para guardar seus pertences pessoais. 
Numa apreciação cuidadosa dos prontuários, percebemos que não existe diálogo possível entre o psiquiatra do hospital e o interno: a fala do paciente serve apenas como "material clínico" que deve ser examinada para se chegar a um diagnóstico. Se o dito louco, por algum motivo não cooperava durante a entrevista, essa recusa era imediatamente considerada como um grave sinal de alguma "doença mental". Caso o paciente tentasse fazer algum comentário sobre o que julgava estar acontecendo, sua verbalização era dada como "ininteligível". Em sua maioria, os psiquiatras demonstravam desinteresse pela opinião dos pacientes.

Um caso que chamou atenção dos médicos no Pavilhão de Observação foi o da paciente C.M.C. (LIVROS DE PRONTUÁRIOS DO PAVILHÃO DE OBSERVAÇÃO E DO H.D.N.M., 1926). Parda, solteira, natural da cidade de Rio Formoso, contava com a idade de 21 anos quando fora encaminhada pelo chefe de polícia para o hospital. Em seus antecedentes históricos, verificou-se que seu pai era muito distraído e parecia apresentar sinais de "perturbação mental". Analfabeta, durante a sua infância contraiu sarampo, varicela e sarna. Era virgem e havia menstruado aos 14 anos de idade. Segundo os médicos, apresentava uma inteligência rudimentar e um caráter triste, violento e colérico. Fazia pouco uso do álcool. Conforme as informações de seu genitor, os primeiros sintomas de sua "desordem mental" ocorreram quando a paciente começou a sentir fortes dores de cabeça e insônias, "desde então ela ficou com o "juízo perturbado". Sua conduta com os companheiros parecia normal, entretanto, frequentemente, brigava com a enfermeira do pavilhão. De difícil adaptação, vivia buscando oportunidade para se expor.

Em seu exame somático, os psiquiatras constataram que a paciente era de estatura média e apresentava pêlos, pulso e pele normal. No "exame psíquico" assinalaram que ela parecia "mais ou menos orientada no tempo e no espaço" e exibia uma consciência enfraquecida. Sua afetividade parecia natural, mas, com frequência, procurava se evadir da instituição. Segundo os psiquiatras, não respondia às perguntas e era dotada de uma memória imperfeita, uma imaginação defeituosa e atitudes agressivas. Após os psiquiatras realizarem detalhadas observações, a paciente foi diagnosticada como uma "degenerada 
indócil e cheia, provavelmente, de defeitos de educação", o que levou seu internamento, com o diagnóstico de "Pychose degenerativa".

Outra ocorrência avaliada pelos psiquiatras foi a do Jovem M.M.P. de cor branca, natural de Pernambuco, solteiro, que deu entrada no dia 11 de junho de 1926 no Pavilhão de Observação, sendo encaminhado pelo chefe de polícia. Quatro dias após, foi transferido para o HDNM. Seus antecedentes hereditários eram reveladores para a psiquiatria da época: pai alcoólatra e sifilítico, mãe falecida com causa de morte tuberculose e três tias epiléticas. Durante a infância contraiu varicela e frequentou a escola por um período de apenas quatro anos. No que diz respeito ao "espírito do doente", os psiquiatras constataram ser uma pessoa de inteligência regular e que apresentava um caráter alegre, violento e colérico. "Tinha hábito de vagabundagem" e fazia uso do álcool.

Durante a anamnese, afirmou o paciente que os primeiros sintomas de sua doença "proveio de um bubão syphilíco" que ainda se encontrava no seu organismo. Afirmou ter insônia e anorexia. Segundo os psiquiatras, apresentava má conduta, era agitado, dormia mal e comia muito. Em relação ao exame somático, foi constatado que o mesmo possuía pêlos e pele normal, assimetria facial, além de várias cicatrizes pela cabeça e pelo corpo. Sua sensibilidade e seus reflexos foram considerados normais. Em relação ao exame psíquico, conforme os médicos, M.M.P. se apresentava bem orientado no tempo e no espaço, possuindo a consciência, a imaginação e a percepção normais. Em seus delírios, os psiquiatras perceberam opiniões de riqueza, satisfação, invenção e "Ideias de anarquia". Finalmente, foi diagnosticado "degenerado em episódios delirantes. Psicose degenerativa”.

Como se pode observar, os psiquiatras da época ainda eram fortemente influenciados pela doutrina da degenerescência de Auguste Morel e Magnam. A análise de inúmeros outros prontuários desse período constata que centenas de outros pacientes tiveram o mesmo diagnóstico, em que eram valorizados, sobretudo, os antecedentes hereditários, os dados antropológicos e as "condutas anti-sociais".

Entre os homens, era grande a incidência de internamentos motivados por doenças venéreas e um número significativo se encontrava hospitalizado devido 
à paralisia provocada pela neurossífilis. O álcool era um fator considerável nas internações desse período.

O consumo abusivo da bebida não era exclusivo de nenhuma camada social, entretanto era entre as pessoas mais pobres da população que se observava uma maior ocorrência de internações para tratamentos psiquiátricos. Os consumidores da bebida, muitas vezes desempregados, moradores dos mocambos do Recife ou de outras cidades, eram diagnosticados degenerados.

Um exemplo é o caso de M.A.S., de 46 anos de idade, casado, que fora encaminhado, no dia 20 de fevereiro de 1928, pelo distrito policial de Bom Jardim ao Pavilhão de Observação. Segundo os exames, além de fazer uso constante da bebida, M.A.S. apresentava sinais visíveis de Estygmas senis de degeneração. Diagnosticado como portador de Psycose Alcoólica, foi dirigido ao Pavilhão de observação e, cinco dias depois, para o Hospital de Doenças Nervosas e Mentais, local em que permaneceu até o dia 15 de dezembro de 1928 (LIVROS DE PRONTUÁRIOS DO PAVILHÃO DE OBSERVAÇÃO E DO H.D.N.M., 1928). Apesar de permanecer internado por quase um ano, as poucas informações que constam no prontuário, não nos permitem fazer uma análise mais ordenada das condições desse paciente durante o período de sua internação.

No hospital, o índice de internação de pessoas portadoras de epilepsia foi significativo. Muito dos epilépticos não tinham sintomas de "doença mental", mesmo assim eram internados para tratamento. É o caso de S.F., de 15 anos de idade, vindo de Bom Jardim, encaminhado pela polícia para o Pavilhão de Observação no dia 20 de fevereiro de 1928. Durante os exames, ficou constatado que o mesmo havia frequentado o espiritismo e era portador de "Estgymas phisicos de degeneração". No dia 16 de março, foi encaminhado para o hospital, tendo recebido alta no dia 13 de junho do mesmo ano.

Nos anos 1920, a epilepsia era considerada pelos médicos uma "doença mental de fundo degenerativo, revelada por uma autointoxicação permanente e uma excitabilidade fácil dos centros corticais e medulares que promovem modificações fundamentais de caráter e descarga motoras, sensoriais e psíquicas de insólita violência (crise ou ataques epiléticos)". Segundo Afrânio Peixoto, os epiléticos eram dotados de estigmas físicos de degeneração e 
possuidores de um caráter "móvel, suspeito, desconfiado, dissimulado, irritável, impulsivo, egoísta, teimoso, cruel". Estigmatizados, eram considerados passivos de "manifestações de periculosidade". Afrânio Peixoto ressaltava que a justiça e a medicina deveriam ficar atentas às reações perigosas provocadas pela epilepsia (PEIXOTO, 1926, p. 261).

Em dois livros de registro feminino, cada um com 50 prontuários, avaliados e diagnosticados pelo Dr. Ulysses Pernambucano no ano de 1927, percebe-se que a população feminina do hospital era bastante jovem, variando na faixa etária entre 18 e 38 anos de idade. Em sua grande maioria, constituía-se por solteiras, muito embora não se pode afirmar que essas pessoas não tivessem relações estáveis. Constatamos também a presença de algumas idosas nas dependências do H.D.N.M. Essa população era constituída por analfabetas ou com "instrução rudimentar" e de cor "parda". Muitas mulheres foram encaminhadas primeiramente ao Pavilhão de Observação pela polícia ou por seus familiares e posteriormente foram internadas como indigentes. Um dado significativo é o número de óbitos no período de internação, sem que a causa mortis fosse apresentada. Em um dos livros pesquisados, das 50 mulheres internadas, 13 vieram a óbito no mesmo ano de sua entrada.

Nas 94 ocorrências registradas nos livros, o diagnóstico mais comum das internações era a psicose maníaco depressiva, muito rara entre os homens. A segunda, degenerescência ou episódios delirantes dos degenerados, contava 15 casos, chamando-nos a atenção o seu número expressivo nos anos 1920. A terceira, confusão mental, somava 10 casos, seguida de outros diagnósticos, como demência senil, epilepsia, alcoolismo, psicose auto-toxica, esquizofrenia, pitiatismo, parafrenica, sífilis cerebral e psicose infecciosa (LIVROS DE PRONTUÁRIOS DO PAVILHÃO DE OBSERVAÇÃO E DO H.D.N.M., 1927). Esses dados demonstram que a teoria da degenerescência ainda estava presente com intensidade nas concepções psiquiátricas do Dr. Ulysses Pernambucano e de seus discípulos (MIRANDA, 2010, p. 78). Entre eles, os doutores Alcides Codeceira, Costa Pinto, Jeferson Ribeiro, Adalberto Cavalcanti e os internos acadêmicos Gildo Neto, Fernando Campelo e Jorge de Sá. No início dos anos 1930, ao assumir a direção do Hospital de Alienados antes H.D.N.M., a convite do interventor Carlos 
A teoria da degeneração e suas implicações no Hospital de Doenças Nervosas e Mentais.

de Lima Cavalcanti, Ulysses Pernambucano criou o Serviço de Fotografia em 1931, através de um contrato com um profissional do ramo, no qual os pacientes passaram a ter suas imagens registradas na ocasião da entrada e da alta hospitalar.

As figuras 6 e 7 representam as primeiras páginas de prontuários do ano de 1928, com pacientes diagnosticados com Episódio Delirante de Degeneração. Em nossas pesquisas, encontramos um número significativo de pessoas diagnosticadas e internadas pelo Dr. Ulysses Pernambucano, conforme analisamos no texto.

Figura 6 - Prontuário do H.D.N.M. $\quad$ Figura 7 - Prontuário do H.D.N.M.
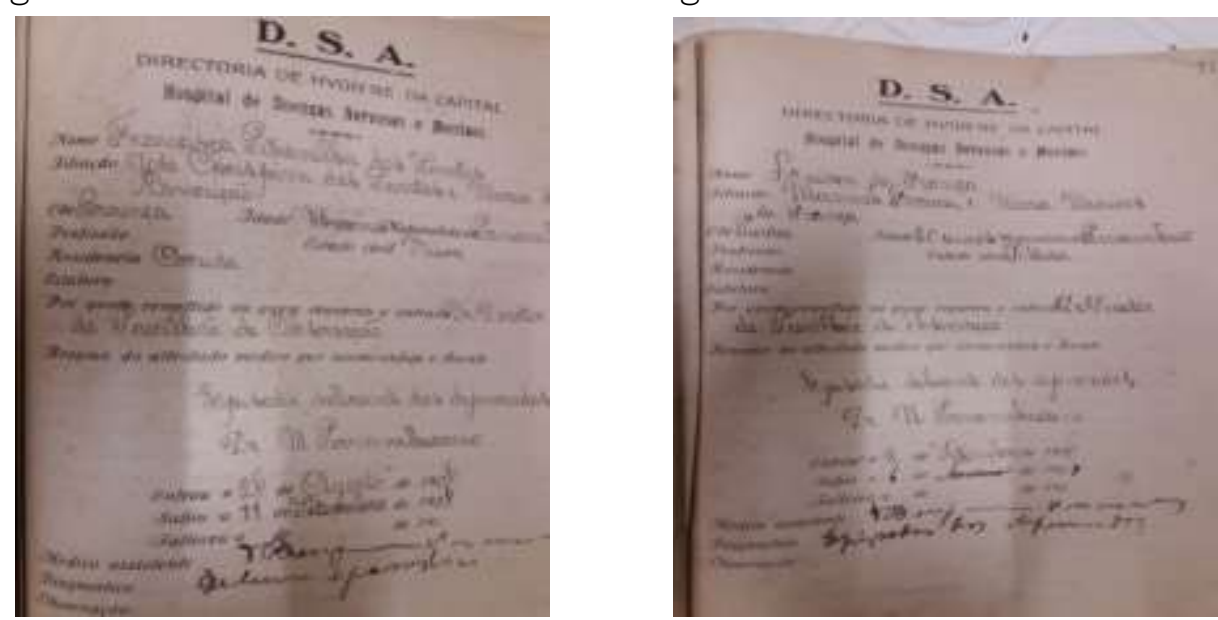

Fonte: Acervo dos Prontuarios do Hospital Ulysses Pernambuco. Livros referentes ao ano de 1928.

É importante ressaltar que esses foram registros de histórias de vida de pessoas pobres, marcadas por sofrimentos e violências institucionalizadas em um espaço com pretensão de cura. Eles foram não apenas diagnosticados como degenerados, mas estigmatizados para sempre como "doentes mentais". Apesar dos equipamentos e dispositivos de controle, vigilância e poder, muitos deixaram nítida sua oposição ao internamento, seja recusando-se a responder às perguntas do médico, seja expressando verbalmente não desejarem permanecer no hospital.

Nesta pesquisa, fica evidente que os psiquiatras da época ainda continuavam influenciados pelas doutrinas da degenerescência de Morel, Magnan e Kraepelin. Esse discurso psiquiátrico, além de culpabilizar diretamente o 
indivíduo e sua hereditariedade pelo seu sofrimento psíquico, ocultava as desigualdades econômicas-sociais, permitindo a distinção de classes, através de um olhar sobre a aparência dos corpos e dos comportamentos fora dos padrões estabelecidos na época. A história da psiquiatria no Brasil, além de ser uma questão de saúde e política, estabelece uma relação de poder muitas vezes camuflada por meio de saberes dotados de uma certa "cientificidade".

\section{Referências}

ARCHIVOS BRASILEIROS HYGIENE MENTAL. [S.l.], Anno II, n. 1, out. 1929.

AUSTREGESILO, Antonio. Clinica neurológica. Rio de Janeiro: Livraria Francisco Alves: 1917.

BERCHERIE, Paul. Os fundamentos da clínica: história e estrutura do saber psiquiátrico. Rio de Janeiro: Jorge Zahar Editor, 1989.

BOLETIM DE HIGINE MENTAL. DOENÇAS MENTAIS EM CRIANÇAS. [S.l.]: Apeje, dez. 1933.

CAPONI, Sandra. Loucos e degenerados: uma genealogia da psiquiatria ampliada. Rio de Janeiro: Editora FIOCRUZ, 2012a.

CAPONI, Sandra. Revista Scientlé Studia, São Paulo, v. 9, n.1, p. 29-50, 2012b.

CARRARA, Sérgio. Crime e loucura: o aparecimento do manicômio judiciário na passagem do século. Rio de Janeiro: EdUERJ; São Paulo: EdUSP, 1998.

CASTEL, Robert. A ordem psiquiátrica: a idade do ouro do alienismo. Rio de Janeiro: Edições Graal, 1978.

COELHO FILHO, Heronides. A psquiquiatria no país do açúcar. João pessoa, 1977.

CUNHA, Maria Clementina Pereira. O espelho do mundo - Juquery, a história de um asilo. Rio de Janeiro: Paz e Terra, 1996.

ENGEL, Magali Gouveia. Os delírios da razão: médicos, loucos e hospícios (Rio de Janeiro 1830-1930). Rio de Janeiro: Editora da Fiocruz. 2001. 
FERRAZ, Flávio Carvalho. Andarilhos da imaginação: um estudo sobre os loucos de rua. São Paulo: Casa do Psicologo, 2000.

FOUCAULT, Michel. O poder psiquiátrico. São Paulo: Martins Fontes, 2006.

FOUCAULT, Michel. Os anormais. São Paulo: Martins Fontes, 2001.

GOFFMAN, Erving. Internados: ensayos sobre la situacioón social de los enfermos mentales. Buenos Ayres: [s.n.], 1972.

GOFFMAN, E. Manicômios, prisões e conventos. São Paulo: Perspectiva, 1987.

FILHO, Heronides.C. A psiquiatria no país do açúcar e outros ensaios. União CIA Editora PB, 1917.

LIVROS DE PRONTUÁRIOS DO PAVILHÃO DE OBSERVAÇÃO E DO H.D.N.M. Recife: [S.l.], 1927.

LIVROS DE PRONTUÁRIOS DO PAVILHÃO DE OBSERVAÇÃO E DO H.D.N.M. Recife: [S.l.], 1928.

LIVROS DE PRONTUÁRIOS DO PAVILHÃO DE OBSERVAÇÃO E DO H.D.N.M. Recife: [S.l.], 1929.

LOPES, Cunha. Higiene mental. Rio de Janeiro: Editores Irmãos Pongetti, 1960.

LOUGAN, Mauricio. Psiquiatria institucional: do hospício a reforma psiquiátrica. Rio de Janeiro: Editora Fiocruz, 2006.

MIRANDA, Carlos Alberto Cunha. Quando a razão começa a julgar a loucura: a institucionalização do sistema manicomial em Pernambuco. Caderno de História- oficina de História: escritos sobre a saúde, doença e sociedade/ Departamento de História da UFPE, [Recife], Ano 7, n. 07, p. xx-xx, 2010.

NEVES, Margarida de Souza. O grande mal do cemitério dos vivos: diagnósticos de epilepsia no hospital nacional de alienados. História, Ciências, Saúde. Manguinhos, Rio de Janeiro, v. 17, supl. 2, p. 293-311, dez. 2010.

OUYAMA, Maurício Noboru. A ordem psiquiátrica e a maquina de curar: o Hospício NossaSenhora da Luz entre Saberes, práticas e discursos sobre a loucura (Paraná, final do Século XIX e início do Século XX). In: WADI, Yonissa Marmitt; SANTOS, Nádia Maria Weber (orgs.). História e loucura: saberes, práticas e narrativas. Urberlândia: EDUFU, 2010. 
PEIXOTO, Afranio. Psicopatologia forense. Rio de Janeiro: Francisco Alves \& comp, 1916.

PHILIPPE, Pinel. Tratado médico filosófico sobre a alienação mental ou a mania. Porto Alegre: Editora da UFRGS, 2007.

PORTOCARRERO, Vera. Arquivo da loucura: Juliano Moreira e a descontinuidade histórica da psiquiatria. Rio de Janeiro: Editora, FIOCUZ, 2002.

Moscoso, Pedro de A. L. Relatório do Dr. Pedro de Attahyde Lobo Moscoso apresentado ao Presidente da Província, datado de 30 de janeiro de 1883. Pernambuco: Typ. Manoel Figueroa de Farias \& Filhos, 1883.

RESENDE, Heitor. Política de saúde mental no Brasil: uma visão histórica. In: CIDADANIA E LOUCURA: políticas de saúde mental no Brasil. Petrópolis: Editora Vozes, 1990. p. 15-75.

RIBEIRO, Daniele Corrêa; LAMB, Nayara Emerick; MASCARENHAS, Wilma Fernandes. Memorias da loucura e as reflexões sobre a reforma psiquiátrica brasileira. Acervo: Revista do Arquivo Nacional, Rio de Janeiro, v. 31, n. 1, p. 4963, jan./abr, 1918.

SETTE, Mário. Arruar. Recife: Secretaria de Educação e Cultura de Pernambuco, 1978.

SOUZA, Vanderlei Sebastião de. A eugenia brasileira e suas conexões internacionais: uma análise a partir das controvérsias entre Renato Kehl e Edgard Roquette-Pinto, 1920-1930. História, Ciências, Saúde. Manguinhos, Rio de Janeiro, v. 23, p. 293-311, 2016.

STEPAN, Nacy leys. A hora da eugenia: raça, gênero e nação na America do Sul. Rio de Janeiro: Editora da Fiocruz, 2005.

VENANCIO, Ana Teresa Acatauassú; BRAGA, André Luiz de Carvalho. Assistência psiquiatrica nacional: narativas para uma politica pública no contexto brasileiro (1940 a 1970). In:WADI, Yonissa Marmitt (org.). Narrativas sobre loucuras, sofrimentos e traumas. 22. ed. Curitiba: Máquina de Escrever, 2016.

WADI, Yonissa Marmitt. Experiencia de vida, experiência de loucura: algumas história sobre mulheres internas no Hospício de São Pedro (Porto Alegre, RS, 1884-1923). História UNISINOS/Universidade do Vale dos Rios dos Sinos, São Leopoldo, v. 10, n. 1, p. 65-79, 2006. 
A teoria da degeneração e suas implicações no Hospital de Doenças Nervosas e Mentais. Recife, PE /1920

Carlos Alberto Cunha Miranda

Universidade do Estado de Santa Catarina - UDESC

Programa de Pós-Graduação em História - PPGH

Revista Tempo e Argumento

Volume 13 - Número 33 - Ano 2021

tempoeargumento@gmail.com 